\title{
UPAYA MENINGKATKAN HASIL BELAJAR GEOGRAFI PADA KOMPETENSI DASAR ATMOSFER DAN DAMPAKNYA TERHADAP KEHIDUPAN DIPERMUKAAN BUMI MELALUI PENERAPAN MODEL PEMBELAJARAN INQUIRY BERBASIS DISKUSI SISWA KELAS X-F SMA NEGERI 54 JAKARTA
}

\author{
Hasanuddin \\ Guru SMA Negeri 54 Jakarta \\ Email: hasanuddin_nrg@yahoo.com
}

\begin{abstract}
ABSTRAK
Penelitian ini bertujuan untuk meningkatkan hasil belajar siswa dalam proses pembelajaran geografi dengan model pembelajaran inquiry berbasis diskusi. Penelitian ini dilaksanakan selama 4 bulan terhitung mulai tanggal 4 februari - 9 mei 2012 di SMA Negeri 54 Jakarta. Penelitian ini menggunakan metode penelitian tindakan kelas yang dilakukan dalam 2 siklus, masing-masing siklus terdiri dari 1 kali pertemuan yang terdiri dari 1) perencanaan, 2) tindakan, 3) observasi, 4) refleksi. Pada pelaksanaan penelitian, peneliti bertindak sebagai pengajar di kelas $X$ dengan dibantu oleh guru lainnya sebagai kolaborator. Siklus pertama didapat skor rata-rata hasil belajar siswa adalah 69,63 karena pada siklus pertama para siswa baru diperkenalkan model pembelajaran Inquiry berbasis diskusi sehingga siswa belum terbiasa dengan model tersebut. Pada siklus kedua diperoleh skor rata-rata hasil belajar siswa adalah 73,88, terdapat peningkatan sebesar 4,25 berarti dengan model pembelajaran ini siswa sudah mulai menemukan cara belajar efaktif dan menarik.
\end{abstract}

\section{Kata kunci : siswa, metode inquiry, hasil belajar}

\section{PENDAHULUAN}

Pendidikan merupakan faktor terpenting dari suatu bangsa hal ini karena melalui pendidikanlah kualitas sumber daya manusia dapat dihasilkan. Kemajuan dan peradaban suatu bangsa di dunia tak bisa dicapai tanpa adanya sumber daya manusia yang handal. Apa artinya kekayaan alam yang melimpah jika manusia tidak mampu mengelola. Jadi untuk menciptakan sumber daya manusia yang berkualitas dan mampu untuk bersaing dengan bangsa lain dibutuhkan pendidikan yang bermutu.

Apabila diperhatikan pelaksanaan pembelajaran geografi di sekolah ada kesan bahwa pelajaran geografi kurang menarik atau dapat dikatakan tidak penting, keadaan ini dapat disebabkan antara lain: karena guru kurang mampu menggunakan metode yang cocok, kurang memanfaatkan media atau kurang mampu menggunakan model/strategi pembelajaran bahkan ada guru yang mendominasi kelas atau teacher centered, tidak mengikuti perkembangan, dengan kata lain guru tidak berkualitas.

Kompetensi pedagogik yaitu kemampuan mengelola pembelajaran termasuk memahami kondisi peserta didik, merancang dan melaksanakan pembelajaran, evaluasi dan tidak kalah penting adalah bagaimana mengembangkan potensi peserta didik agar dapat mengaktualisasikan dirinya.Kompetensi kepribadian yang mantap, dewasa, arif dan bijaksana, tidak emosional, berwibawa, berahlak mulia sehingga menjadi teladan bagi peserta didik. Sedangkan kompetensi sosial yaitu memiliki kemampuan berkomunikasi baik dengan siswa atau peserta didik, sesama rekan pendidik, orang tua dan masyarakat disekitarnya. Di dalam Kurikulum Tingkat Satuan Pendidikan SMA Negeri 54 Jakarta Mata Pelajaran Geografi diberikan dengan tujuan agar siswa kelas $X$ memperoleh kemampuan memahami dan memecahkan permasalahan geografi pada kompetensi dasar menganalisis atmosfer dan dampaknya terhadap kehidupan di muka bumi. Materi tersebut diberikan kepada siswa dalam bentuk inquiry tentang fenomena-fenomena atmosfer apa yang sedang terjadi dan di diskusikan dalam kegiatan belajar mengajar sehingga siswa menemukan masalah- masalah atmosfer disekitarnya dan dipecahkannya dalam kegiatan belajar melalui diskusi. Pembelajaran dengan penerapan model pembelajaran inquiry 
berbasis diskusi pada materi tersebut diharapkan siswa menjadi aktif dan efektif karena siswa menemukan permaslahan nyata yang ditemukan dilapangan. Melalui pengajaran geografi siswa mampu mengembangkan kompetensi untuk berpikir secara logis dan memiliki pengetahuan tentang masalah-masalah geografi,yang dapat digunakan sebagai bekal dalam kehidupan sekarang dan masa yang akan datang terlebih dalam jaman yang makin kompetitif.

Pendekatan model inquiry berbasis diskusi tentang materi atmosfer dan dampaknya terhadap kehidupan di permukaan bumi memiliki keunggulan dan dapat mendukung pembelajaran geografi dikelas X-F serta meningkatkan keaktifan siswa dalam kegiatan belajar mengajar sehingga dapat meningkatkan kualitas pembelajaran. Oleh karena itu peneliti mencoba untuk menerapkannya dalam Peneiitian Tindakan Kelas (PTK) dengan tujuan untuk meningkatkan proses dan hasil belajar siswa serta kemandirian dan keaktifan siswa sesuai dengan kurikulum yang ada , dengan judul PTK: Upaya meningkatkan pembelajaran geografi tentang atmosfer melalui penerapan model pembelajaran inquiry berbasis diskusi pada kelas X-F di SMA Negeri 54 Jakarta.

\section{METODOLOGI PENELITIAN}

Penelitian dilaksanakan di kelas X-F SMA Negeri 54 Jakarta pada semester genap tahun pelajaran 2011 - 2012. Lokasi penelitian Negeri 54 Jl. Jatinegara Timur IV Kecamatan Jatinegara Jakarta Timur. Pelaksanaan penelitian dilakukan selama 4 bulan. Dimulai dari tanggal 6 Februari sampai dengan 10 Mei 2012. Penelitian ini menggunakan metode Penelitian Tindakan Kelas yang dilaksanakan dalam dua siklus dengan tiga pertemuan melalui tahapan perencanaan, pelaksanaan, observasi dan refleksi. Instrumen penilaian kelas digunakan untuk mengumpulkan data hasil belajar disamping hasil dari lembar observasi atas keaktivan siswa.

\section{HASIL PENELITIAN Gambaran tentang Siklus}

Data hasil penelitian adalah data yang diperoleh dari hasil observasi siswa, quesioner, dan tes hasil belajar siswa setelah pelaksanaan tindakan siklus I dan siklus II.

Data yang dianalisa secara kualitatif yaitu data yang diperoleh dari hasil observasi aktivitas siswa pada kegiatan diskusi maupun dalam kegiatan observasi dilapangan pada setiap kali pertemuan, sedangkan data yang dianalisis secara kuantitatif adalah skor tes hasil belajar siswa setelah siklus I dan siklus II. Skor tersebut dianalisis dengan menggunakan statistika deskriptif yaitu skor rata-rata, standar deviasi, median, frekuensi dan persentase nilai terendah dan nilai tertinggi yang dicapai siswa pada tes tersebut.

\section{Siklus Pertama}

Berdasarkan hasil pengamatan guru yang bertugas sebagai peneliti dalam pelaksanaan penelitan tindakan kelas, melalui model pembelajaran inquiry berbasis diskusi. Pelaksanaan siklus 1, belum seluruh siswa aktif berpartisipasi, serta ketergantungan terhadap penjelasan guru masih sangat dominan pada saat siswa mengadakan presentasi kelompok, sebagian siswa asyik bicara dengan teman atau tidak mendengarkan pada saat presentasi kelompok mlain.

Media yang digunakan dalam penelitian ini adalah data hasil belajar diambil dengan memberikan tugas dan hasil tes siswa,data mengenai siswa yang aktif menyampaikan pendapat dalam diskusi, pelaporan hasil observasi, catatan siswa tentang pengamatan lapangan tentang penyinaran matahari, pengukuran suhu udara,pengamatan kecepatan angin, pengamatan awan, di sekitar sekolah, dan nilai tugas yang menggambarkan keaktifan siswa, antusias siswa, keberanian siswa dan kerjasama siswa dalam pelaporan tugas. 
Tabel 1. Hasil Angket Pelaksanaan Pembelajaran dengan Model Inquiry Berbasis Diskusi pada Siswa Kelas X.F SMA Negeri 54 Jakarta

\begin{tabular}{llcccccccccc}
\hline \multirow{2}{*}{ No } & \multicolumn{1}{c}{ Jawaban } & 1 & 2 & 3 & 4 & 5 & 6 & 7 & 8 & 9 & 10 \\
& & 16 & 6 & 11 & 18 & 20 & 23 & 16 & 5 & 22 & 11 \\
\hline 1 & Belum pernah & 12 & 13 & 6 & 6 & 7 & 8 & 10 & 18 & 9 & 15 \\
2 & Jarang & 6 & 8 & 10 & 9 & 7 & 5 & 7 & 8 & 5 & 7 \\
3 & Kadang-kadang & 6 & 13 & 13 & 7 & 6 & 4 & 7 & 9 & 4 & 7 \\
4 & Selalu & 40 & 40 & 40 & 40 & 40 & 40 & 40 & 40 & 40 & 40 \\
\hline
\end{tabular}

Sumber: Penelitian 2012

Tabel 2. Persentase jawaban Quesioner dari Hasil Angket

\begin{tabular}{|c|c|c|c|c|c|}
\hline \multirow{2}{*}{ No. } & \multicolumn{4}{|c|}{ Presentase Jawaban Quesioner } & \multirow{2}{*}{ Jumlah } \\
\hline & Belum Pernah & Jarang & Kadang kadang & Selalu & \\
\hline 1 & 40 & 30 & 15 & 15 & 100 \\
\hline 2 & 15 & 33 & 20 & 32 & 100 \\
\hline 3 & 28 & 15 & 25 & 32 & 100 \\
\hline 4 & 45 & 15 & 23 & 17 & 100 \\
\hline 5 & 50 & 18 & 17 & 15 & 100 \\
\hline 6 & 58 & 20 & 12 & 10 & 100 \\
\hline 7 & 40 & 25 & 18 & 17 & 100 \\
\hline 8 & 13 & 45 & 20 & 22 & 100 \\
\hline 9 & 55 & 23 & 12 & 10 & 100 \\
\hline 10 & 28 & 37 & 18 & 17 & 100 \\
\hline
\end{tabular}

Berdasarkan hasil pengolahan data secara kualitatif tentang pembelajaran model inquiry berbasis diskusi diperoleh angka $40 \%$ siswa belum pernah mendapatkan model pembelajaran inquiry berbasis diskusi, $45 \%$ siswa mengatakan belum pernah mengkontruksi sendiripengetahuan dan ketrampilan tanpa mendapatkan ceramah dari guru, $50 \%$ siswa mengatakan belum pernah melakukan pemecahan masalah dalam kegiatan pembelajaran yang ditampilkan, $58 \%$ siswa mengatakan belum pernah guru mengurangi ceramah dalam penyampaian materi, $40 \%$ ssiswa mengatakan belum pernah melakukan kegiatan membaca, mengamati, menganalisis, dan menyimpulkan suatu masalah dalam kegiatan belajar mengajar, dan $55 \%$ siswa mengatakan belum pernah fokus kegiatan belajar yang berpindah dari guru ke siswa, sehingga peneliti berkesimpulan model pembelajaran inquiry berbasis diskusi untuk siswa Kelas X.F SMA Negeri 54 Jakarta perlu di kembangkan dalam kegiatan belajar mengajar, agar hasil belajar siswa meningkat.

Berdasarkan hasil observasi yang dilakukan oleh guru sebagai peneliti dengan menggunakan format observasi diperoleh keterangan bahwa:

1. Partisipasi Siswa

Pada kegiatan kelompok, siswa terlihat semua berpartisipasi, bekerja sama dalam menyelesaikan tugas kelompoknya. Meraka terlihat berusaha mencari referensi atau bahan rujukan yang sesuai dengan materi dan itu semua telah dipersiapkan dari rumah. Hal ini tentu sangat menggembirakan dan sewaktu melakukan presentasi kelompok, anggota kelompok berpartisipasi dan memberikan kontribusi jawaban terhadap pertanyaan yang masuk. Hal ini terlihat pada :

a.Pada saat anggota kelompok berdiskusi untuk mengidentifikasi ciri-ciri masing -masing lapisan atmosfer mulai nampak keseriusan siswa karena guru sebagai peneliti memantau perilaku siswa dalam diskusi dan memberitahukan kepada siswa siapa yang tidak aktif dalam diskusi maka tidak mendapatkan nilai.

b. Masing-masing kelompok mengukur suhu udara dengan alat thermometer suhu kemudian mencatat suhu udara pada pagi hari jam 06.30, jam 12.00 dan jam 15.00 pada lembaran kerja 
siswa, kemudian siswa saling mencocokan besar suhu yang dicatat antara satu kelompok dengan kelompok lain dan menghitung selisih amplitudu suhu harian .

c.Dalam pencatatan arah dan kecepatan angin dengan menggunakan Skala Beufort disekitar lingkungan sekolah maka siswa dapat menentukan arah datangnya angin dari mana, kecepatan angin, dan nama angin yang bertiup sesuai dengan skala Beufort.

d.Dalam pengamatan awan masih ada tiga kelompok yang mengidentifikasi bentuk dan ketinggian awan yang salah karena mereka hanya memperikirakan ketinggian awan dan bentuk tanpa mencocokkan gambar yang telah diperlihatkan di power point.

e.Dalam pembuatan climograf tentang curah hujan dan suhu di kota A semua kelompok membuatnya dengan benar

f. Dalam perkiraan hujan atau berawan di lima wilayah dengan menggunakan data suhu udara dan kelembaban maksimum semua kelompok dapat menjawab dengan benar.
g.Dalam pembuatan grafik pola hujan equator, moonson dan lokal para siswa dapat membuat dengan benar dan dapat mengetahui secara langsung curah hujan yang tertinggi pada ketiga pola tersebut dan bisa membedakan pola-pola hujan yang jatuh di Indonesia pada bulan-bulan tertentu.

\section{Kemampuan menganalisa}

Kemampuan ini terlihat pada waktu mereka menyampaikan pendapat kelompok pada waktu presentasi, masih kelihatan ragu-ragu memberikan jawaban atas pertanyaan dari kelompok lain dan masih mengharapkan jawaban dari anggota kelompoknya.

Pada siklus 1 ini dilaksanakan tes hasil belajar yang berbentuk ulangan harian setelah penyajian. Dari hasil tes ulangan yang dilakukan oleh peneliti, terlihat adanya peningkatan perolehan nilai bila dibandingkan sebelum pelaksanaan siklus. Adapun data hasil belajar siswa kelas X.F sebelum tindakan dilaksanakan dan sesudah tindakan dilaksanakan pada siklus I dapat dilihat pada tabel berikut ini.

Tabel 3. Nilai Hasil belajar Siswa sebelum tindakan dan sesudah tindakan pada siklus 1.

\begin{tabular}{ccc}
\hline Statistik & \multicolumn{3}{c}{ Nilai Statistik } \\
& Sebelum Tindakan & Sesudah Tindakan \\
\hline Nilai Tertinggi & 76 & 80 \\
NilaiTerendah & 60 & 58 \\
Rentang Nilai & 16 & 22 \\
Nilai Rata-Rata & 69,05 & 74,8 \\
Standar Deviasi & 4,44 & 5,58 \\
\hline
\end{tabular}

Sumber: Penelitian 2012

Dari hasil ulangan setelah siklus I pertama selesai dilakukan 40 siswa yang ikut tes diperoleh ratarata perolehan nilai 74,8 , dari nilai ideal yang mungkin dicapai adalah 100. Hal ini disebabkan karena masih kurangnya perhatian siswa dalam melakukan kegiatan lain selama proses pembelajaran berlangsung.

Apabila nilai hasil belajar siswa dikelompokkan kedalam 5 kategori maka diperoleh persentase nilai hasil belajar seperti yang disajikan pada tabel berikut.

Tabel 4. Frekuensi dan Persentase Nilai Hasil Belajar Geografi Jakarta Pada Siklus 1

\begin{tabular}{cccc}
\hline Nilai & Kategori & Frekuensi & Persentase $(\%)$ \\
\hline $0-54$ & Sangat rendah & 0 & 0 \\
$55-64$ & Rendah & 3 & 7,5 \\
$65-79$ & Sedang & 27 & 67,5 \\
$80-89$ & Tinggi & 10 & 25 \\
$90-100$ & Sangat tinggi & 0 & 0 \\
& Jumlah & 40 & 100 \\
\hline
\end{tabular}

Sumber: Penelitian 2012

UPAYA MENINGKATKAN HASIL BELAJAR GEOGRAFI PADA KOMPETENSI DASAR ATMOSFER DAN 
Tabel di atas menunjukkan bahwa nilai rata-rata hasil belajar siswa kelas X.F SMA Negeri 54 Jakarta setelah diberi tindakan pada siklus 1 berada pada kategori sedang. Selanjutnya jika nilai hasil belajar siswa pada siklus 1 dikelompokkan berdasarkan nilai Kriteria Ketuntasan Minimal ( KKM ) yaitu 75 untuk mata pelajaran geografi maka persentase ketuntasan belajar siswa dapat dilihat pada tabel berikut:

Tabel 5. Deskripsi Ketuntasan Hasil Belajar Geografi pada Siklus 1.

\begin{tabular}{cccc}
\hline Skor & Kategori & Frekuensi & Persentase $(\%)$ \\
\hline $0-74$ & Tidak tuntas & 15 & 37,5 \\
$75-100$ & Tuntas & 25 & 62,5 \\
& Jumlah & 40 & 100 \\
\hline
\end{tabular}

Sumber: Penelitian 2012

Dari tabel di atas menunjukkan bahwa persentase ketuntasan kelas sebesar $62,5 \%$ yaitu 25 siswa dari 40 termasuk dalam kategori tuntas, dan $37,5 \%$ atau 15 siswa dari 40 termasuk dalam kategori belum tuntas. Ini berarti persentase ketuntasan belum mencapai indicator keberhasilan sehingga penelitian dilanjutkan ke siklus ke II.

\section{Siklus Kedua}

Berdasarkan hasil observasi yang dilakukan oleh guru sebagai peneliti dengan menggunakan format observasi diperoleh keterangan bahwa sikap dan prilaku siswa dalam kerja kelompok untuk observasi dilapangan tentang pengamatan cuaca hasilnya sebagai berikut.

Tabel 6. Sikap dan prilaku siswa dalam kerja kelompok dalam pengamatan cuaca

\begin{tabular}{|c|c|c|c|c|c|c|c|c|c|}
\hline Kelompok & 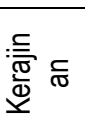 & 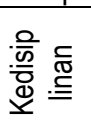 & 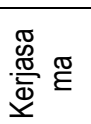 & 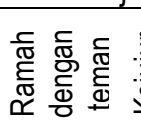 & 产 & 哥 & 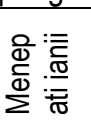 & $\frac{\frac{c}{0}}{\frac{c}{E}}$ & 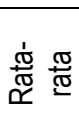 \\
\hline 1 & 4 & 4 & 5 & 5 & 5 & 4 & 5 & 32 & 91 \\
\hline 2 & 4 & 4 & 5 & 5 & 5 & 4 & 5 & 32 & 91 \\
\hline 3 & 4 & 4 & 5 & 5 & 5 & 4 & 4 & 31 & 88 \\
\hline 4 & 3 & 3 & 4 & 5 & 5 & 3 & 4 & 27 & 77 \\
\hline 5 & 5 & 5 & 5 & 5 & 5 & 4 & 5 & 34 & 97 \\
\hline 6 & 4 & 4 & 5 & 5 & 5 & 4 & 5 & 32 & 91 \\
\hline 7 & 3 & 3 & 4 & 5 & 5 & 4 & 4 & 28 & 80 \\
\hline 8 & 4 & 4 & 5 & 5 & 5 & 4 & 5 & 32 & 91 \\
\hline
\end{tabular}

Sumber: Penelitian 2012

$\begin{array}{llll}\text { Keterangan: } & & & \\ \text { Sangat baik } & =5 & \text { Kurang } & =2 \\ \text { Baik } & =4 & \text { Sangat kurang } & =1 \\ \text { Cukup } & =3 & & \end{array}$

Tabel di atas menunjukan bahwa dengan model pendekatan inquiry berbasis diskusi dalam pembelajaran dimana mereka saling membelajarkan, yang cepat belajar didorong untuk membatu yang lambat belajar, yang memilki kemampuan tertentu didorong untuk menularkannya pada yang lain sehingga para siswa semangat dan keseriusannya dalam pembelajaran sangat tinggi. Hal ini bisa dilihat pada grafik sikap dan prilaku siswa dalam kerja kelompok baik dilapangan maupun dalam diskusi kelompok.

Berdasarkan hasil diskusi yang dilakukan oleh siswa diperoleh keterangan sebagai berikut : a. Menentukan iklim berdasarkan garis lintang semua kelompok menjawab dengan benar.

b.Menentukan tipe iklim, nilai $Q$, sifat dan vegetasi yang tumbuh menurut Schimidt dan Ferguson para kelompok dapat menjawab dengan benar karena mereka sudah 
mengetahui dengan pasti kriteria bulan basah dan bulan kering

c. Menentukan tipe iklim suatu wilayah menurut W.Koppen 7 kelompok menjawab dengan benar, dan 1 kelompok menjawab salah karena menginterpretasi curah hujan suhu di wilayah $\mathrm{E}$ keliru.

d.Dalam evaluasi jumlah soal 50 pilihan ganda, dari 40 siswa yang ikut tes diperoleh rata-rata perolehan nilai 78,00 , dan 28 siswa memperoleh 75 keatas dan 12 siswa memperoleh nilai ulangan 75 atau sesuai standar ketuntasan minimal.

Dari hasil ulangan setelah siklus kedua selesai dilakukan 40 siswa yang ikut tes diperoleh rata-rata perolehan nilai 79,5 , dengan standar deviasi 6,527 setelah dikategorisasikan berada dalam kategori tinngi. Hal ini menunjukkan bahwa dengan menggunakan pembelajaran model ingquiry berbasis diskusi dapat meningkatkan proses dan hasil belajar siswa kelas X.F SMA Negeri 54 Jakarta.

Tabel 7. Frekuensi dan Persentase Nilai Hasil Belajar Geografi Pada Siklus 2

\begin{tabular}{cccc}
\hline Nilai & Kategori & Frekuensi & Persentase (\%) \\
\hline $0-54$ & Sangat rendah & 0 & 0 \\
$55-64$ & Rendah & 0 & 0 \\
$65-79$ & Sedang & 20 & 50 \\
$80-89$ & Tinggi & 17 & 42,5 \\
$90-100$ & Sangat tinggi & 3 & 7,5 \\
& Jumlah & 40 & 100 \\
\hline
\end{tabular}

Sumber: Penelitian 2012

Dari tabel 4.8 menunjukkan bahwa nilai rata-rata hasil belajar siswa kelas X.F SMA Negeri 54 Jakarta setelah diberi tindakan pada siklus dua berada pada kategori sedang dan tinggi, dan perbandingan antara kategori sedang dan tinggi adalah $50 \%$ berbanding $50 \%$ sehingga peneliti berkesimpulan siklus kedua akan berakhir karena sudah mencapai indicator keberhasilan.
Selanjutnya jika nilai hasil belajar siswa pada siklus dua dikelompokkan berdasarkan nilai Kriteria Ketuntasan Minimal ( KKM ) yaitu 75 untuk mata pelajaran geografi maka persentase ketuntasan belajar siswa dapat dilihat pada tabel berikut:

Tabel 8. Deskripsi Ketuntasan Hasil Belajar Geografi pada Siklus 2.

\begin{tabular}{clcc}
\hline Skor & Kategori & Frekuensi & Persentase $(\%)$ \\
\hline $0-74$ & Tidak tuntas & 6 & 15 \\
$75-100$ & Tuntas & 34 & 85 \\
& Jumlah & 40 & 100
\end{tabular}

Sumber: Penelitian 2012

Dari tabel di atas, diketahui bahwa persentase ketuntasan kelas sebesar $85 \%$ yaitu 34 siswa dari 40 termasuk dalam kategori tuntas, dan 15 $\%$ atau 6 siswa dari 40 termasuk dalam kategori belum tuntas. Ini berarti persentase ketuntasan sudah mencapai indicator keberhasilan sehingga penelitian berakhir pada siklus ini.

\section{Analisis terhadap Hasil di Dua Siklus}

Kemampuan ini terlihat pada waktu mereka menyampaikan pendapat kelompok serta waktu menjawab pertanyaan dari kelompok lain, mereka percaya diri berdasarkan kemampuan yang diperoleh karena adanya refensi yang mereka miliki.

Dari hasil tes belajar yang dilakukan oleh peneliti, terlihat adanya peningkatan hasil belajar siswa. Hal lain yang tidak kalah penting adalah bahwa kelas menjadi lebih aktif, suasana menyenangkan dan dinamis, meraka selalu siap dan tepat waktu. Untuk mengukur prestasi belajar untuk mengukur penguasaan pengetahuan yang 
telah dimilikinya, maka peneliti melakukan ulangan harian, hasilnya sebagai berikut:
Adapun data hasil belajar siswa kelas X.F sesudah tindakan dilaksanakan pada Siklus I dan siklus II dapat dilihat pada tabel berikut.

Tabel 9. Nilai Hasil belajar Siswa sesudah tindakan pada siklus pertama dan siklus kedua

\begin{tabular}{ccc}
\hline Statistik & \multicolumn{2}{c}{ Nilai Statistik } \\
& Siklus 1 & Siklus 2 \\
\hline Nilai Tertinggi & 80 & 90 \\
NilaiTerendah & 58 & 65 \\
Rentang Nilai & 22 & 25 \\
Skor rata-rata & 74,8 & 79,5 \\
Standar Deviasi & 6,00 & 6,527 \\
\hline Sumber: Penelitian 2012 & \multicolumn{2}{c}{}
\end{tabular}

\section{KESIMPULAN}

Berdasarkan hasil penelitian yang telah dilakukan melalui model pembelajaran inquiry berbasis diskusi pada mata pelajaran geografi siswa kelas X.F SMA Negeri 54 Jakarta dapat disimpulkan sebagai berikut:

1. Model pembelajaran inquiry berbasis diskusi dapat meningkatkan proses belajar siswa pada mata pelajaran geografi terlihat dari aktivitas siswa dalam berdiskusi dan melakukan pengamatan suhu, angin dan awan dilapangan

2. Model inquiry berbasis diskusi terbukti dapat meningkatkan hasil belajar siswa yaitu sebelum tindakan nilai rata-rata yang dperoleh siswa 69,5 sesudah tindakan nilai rata-rata pada siklus satu 74,8 dan siklus kedua 79,5 .

3. Setelah pelaksanaan tindakan pada siklus 1 dan siklus ke 2 hasil ulangan yang diperoleh yaitu Siklus 1 nilai rata-rata 74,8 , nilai tertinggi 80 , nilai terendah 58 ,pada siklus ke 2 hasilnya yaitu nilai rata-rata 79,5 , nilai tertinggi 90 , terendah 65 . Ini menunjukkan bahwa dengan model pembelajaran inquiry berbasis diskusi terjadi peningkatan hasil belajar dari siklus 1 ke sikulus 2 sebesar 4.7 point.

\section{DAFTAR PUSTAKA}

Djamariah, 2006. Syaiful Bahri, Strategi Belajar Mengajar, Jakarta: Rieneka Cipt.

Budiningsih, Asri C Kansil, 2005. Belajar dan Pembelajaran, Jakarta: Rieneka Cipta.
Dakir, 1983. Dasar-dasar Psikologi. Yogyakarta: IKIP

Dimyati dan Mudjiono, 2002. Belajar dan Pembelajaran. Jakarta: Rieneka Cipta,

Hamid, Hasan, 1996. Pendidikan IImu Pengetahuan Sosial. Jakarta: Proyek Pendidikan Tenaga Akademik.

Hakim Thursam, 2000. Belajar secara Efektif. Jakarta: Puspa Swara,

Mulyasa, 2005. Menjadi Guru Profesional, Bandung: Remaja Rosda Karya.

Mohamad Surya, 2002. Menjadi Guru Profesional, Bandung : Remaja Rosda Karya.

Nurhadi, 2007. Pembelajaran Kontekstual dan Penerapannya dalam KBK, Malang: Universitas Negeri Malang,

Nurani, Yuliani. 2003.Strategi Pembelajaran. Jakarta: Universitas Terbuka.

Purwanto, Ngalim. 1994.Teknik-teknik Evaluasi Pendidikan. Jakarta: Nasco.

NK, Rustiyah. 1994. Didaktik Metodik, Jakarta: Bum! Aksara.

Sudjana, Nana. 1999. Penilaian Hasil Belajar Mengajar. Bandung: Remaja Rosda Karya.

Suhardjono, 2011. Pertanyaan dan Jawaban di sekitar Penelitian Tindakan Kelas dan Tindakan Sekolah.Malang : Cakrawala Indonesia LP3 Universitas Negeri Malang.

Sri Rahayu, Endang. 2012. Metode Penelitian Khusus tentang Action Reseach, Jakarta: Universitas Negeri Jakarta. 
Sanjaya Wina, 2007. Strategi Pembelajaran Berorientasi Standar Proses Pendidikan, Jakarta: Kencana Prenada Media Group

Trianto, 2011, Mendesain Model Pembelajaran Inovatif Progresif, Konsep,Landasan, dan Implementasinya pada Kurikulum Tingkat Stuan Pendidikan, Jakarta : Kencana Prenada Media Group.
Waluya Bagja. 2009. Memahami Geogafi SMA/MA kelas X Semester 1 dan 2. Jakarta: Pusat Perbukuan Departemen Pendidikan Nasional

Wittherington, HG. 1991. Psikologi Pendidikan Terjemahan M. Buchori, Jakarta : Rieneka Cipta. 